\title{
Effect of Rootstock on Plant Growth and Fruit Quality of Sweet Orange (Citrus sinensis var. Valencia late)
}

\author{
Polu Parameshwar ${ }^{*}$, P.S. Joshi and P.K. Nagre \\ De partment of Horticul ture, Dr. Panjabrao Deshmukh Krishi Vidyapeet, Akola-444104, \\ Maharashtra, India \\ *Corresponding author
}

\section{A B S T R A C T}

\begin{tabular}{|l|}
\hline K e y w o r d s \\
Citrus, Rootstocks, \\
Valencia orange, \\
Plant height, Fruit \\
quality
\end{tabular}

\section{Introduction}

Rootstock type has important role in quantity and quality of growth and development and crop production in citrus. Citrus rootstocks differ in compatibility to kinds of soils, manner of root dispersion and affiliation to micorhyza. This object lead to difference in leaf mineral elements concentration or leaf of budded cultivars on them and finally affect vegetative growth and fruit quantity and quality. In a budded tree, rootstock type affects many scion properties such as plant height, plant spread and Plant volume. Highest Number of fruits per plant, number of $\mathrm{kg}$ per
Effect of citrus rootstock Rough lemon (C. limon Linn. Burn Citrus jemberi) on plant growth and fruit quality of sweet orange varieties like Pera, Pine apple, Jaffa, Washington novel, Hamlin, Valencia late, Sathgudi and Blood red malta evaluated at All India Coordinated Research Project on Tropical Fruits (Citrus), Dr. Panjabrao Deshmukh Krishi Vidyapeeth, Akola 2012-13. Budded Valencia late orange on rootstock were grown in pred well drained and maintained free from weeds. The physical and chemical properties of soil are as suitable. Results showed that rootstock had significant effect on growth and development as well as Fruit quality of Valencia late. Highest Plant height $(4.42 \mathrm{~m})$, Plant mean spread $(4.17 \mathrm{~m})$ and Plant volume $\left(40.31 \mathrm{~m}^{3}\right)$ on Rough lemon rootstock. Rootstock types had significant effect on highest Number of fruits per plant (232.76), number of $\mathrm{kg}$ per plant (32.75) as well as Fruit quality like highest juice percentage (53.15), TSS (12.56 brix), Acidity (1.01\%) and Ascorbic acid (57.86 mg/100 $\mathrm{ml}$ juice) were budded on rough lemon rootstock. 
Fruit quality of Valencia orange in Akola condition.

\section{Materials and Methods}

Eight Sweet orange varieties viz. Pera, Pineapple, Jaffa, Washington navel, Hamlin, Valencia late, Sathgudi and Blood red malta were selected for study. The studies were conducted at All India Coordinated Research Project on Tropical Fruits (Citrus), Dr. Panjabrao Deshmukh Krishi Vidyapeeth, Akola 2012-13. All the trees were of same age (12 years) raised on Rough Lemon ( $C$. limon Linn. Burn). Experiment was laid out in RBD with three replications. The plants were protected against attack of insects, pests and diseases. Considering maturity time, fruits of different varieties were harvested at different times. Physicochemical analysis of fruit of these varieties was carried out in the laboratory.

All plants were given the standard cultural practices. The plants were watered by Drip system. NPK @ 1500-750- 500 g along with $60 \mathrm{~kg}$ FYM per plant were applied during study period. Nitrogen was applied in three split doses i.e. before flowering, at pea stage and during August, 2012-13. The height of the plant was measured in meters from ground level to tip of the plant by marked bamboo. The spread of tree was recorded by measuring maximum spread in North-South and EastWest directions in meters with the help of marked bamboo calculated mean spread of plant in Ambia. The plant volume of selected plants were computing using formula suggested by Roose et al., (1986) and recorded in cubic meter

Plant volume $(V)=4 / 6 \times \pi \times h \times r^{2}$

Where,

$\mathrm{H}=$ height of plant,

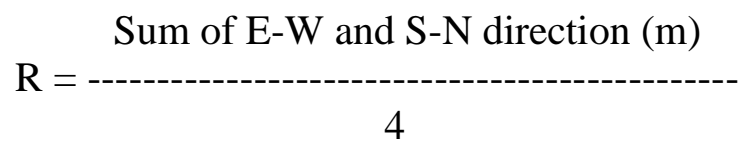

E-W = East-West, N-S= Narth - South

The TSS was measured by digital refrectometer and the percentage of acidity was determined by an anhydrous citric acid by nitrogen the dilute juice against $0.1 \mathrm{~N}$ sodium hydroxide by using phenolphthalein indicator (AOAC, 1985).

Formula: $1 \mathrm{ml}$ of $0.1 \mathrm{~N} \mathrm{NaOH}=0.0064 \mathrm{~g}$ of citric acid was employed.

Ascorbic acid present in fruit from each treatment was estimated in milligrams of ascorbic acid /100 $\mathrm{ml}$ of fruit juice. One $\mathrm{ml}$ of fruit juice taken and blended with 3 percent meta phosphoric acid (HPO3) and volume was made to $100 \mathrm{ml}$ with HPO3.The contents after shaking well were filtered with What man No.1 filter paper. Ten $\mathrm{ml}$ of the filtrate was titrated against dye solution of 2,6dichlorophenol till light colour persisted for at least 15 seconds. The titration values were put the following formula to calculate ascorbic acid content.

Vitamin C $(\mathrm{mg} / 100 \mathrm{~g})=\frac{\mathrm{e} \times \mathrm{d} \times \mathrm{b}}{\mathrm{c} \times \mathrm{a}}$

0.5

Dye factor $(\mathrm{d})=$-------------------------------Standardization of dye solution.

Where,

$\mathrm{a}=$ weight of sample

$\mathrm{b}=$ volume made with meta phosphoric acid

$\mathrm{c}=$ volume of aliquot taken for estimation

$\mathrm{d}=$ dye factor

$\mathrm{e}=$ average burette reading for sample. 


\section{Results and Discussion}

Maximum height $(4.42 \mathrm{~m})$ was attained by Valencia late (Table 1) while Pera attained the lowest height $(2.81 \mathrm{~m})$ Madhavi and Babu (2003) observed similar variation in height of tree among the seven varieties of sweet orange and they found the maximum height of tree in Jaffa $(4.28 \mathrm{~m})$ and minimum in Blood Red Malta $(2.41 \mathrm{~m})$. Shinde et al., (2004) also reported that the height of tree in different kagzi lime varieties, further Ingle et al., (2004) also reported maximum plant height in PDKV lime $(4.51 \mathrm{~m})$ compare to other varieties.

The highest spreading variety Valencia late $(4.17 \mathrm{~m})$ whereas the least spreading variety was Pera (3.06 m) variety. Patil et al., (2007) studied the spread of tree of two sweet or-ange varieties and observed maximum spread was recorded in Nucellar and minimum spread was re-corded Sathgudi. Maximum plant volume was observed in variety Valencia late (40.31 m3) followed by Blood red malta $(33.07 \mathrm{~m})$ whereas the variety Pera recorded the minimum tree volume $(13.81 \mathrm{~m} 3)$. This may due to the formation of bottleneck type bud union configuration, which might have restricted the movement of nutrient to the scion and rather accumulation of higher amount of food material through photosynthesis in the stock and also these differences may be different potential of each variety (Aziz, 1963).

Significantly maximum number of fruit per plant was recorded in variety Valencia late (232.76) which at par with variety Sathgudi (120). The minimum no. of fruits per plant was recorded for variety Pera (62.83). Similar trends were observed by Mehrotra et al., (1977) reported on Valencia late and recorded maximum number of fruits per tree (101.1) on Troyer rootstock. Richardson et al., (1991) also studied performance of Nucellar and Sathgudi and reported more number of fruits
(249.9) in Nucellar whereas Sathgudi produced (201.3) fruits per plant. Ahmed et al., (2006) also finding same result on evaluation of some exotic cultivars of sweet orange in Punjab conditions, better growth performance observed in Mosambi variety and also they reported more number of fruits per tree (345.75). Nikhare (2002) reported same result in acid lime.

Significantly maximum fruit yield was observed in variety Valencia late (32.75 $\mathrm{kg} / \mathrm{plant})$ followed by variety Sathgudi (29.32 $\mathrm{kg} / \mathrm{plant}$ ). While the minimum fruit yield per tree was found in variety Pera (10.09 $\mathrm{kg} / \mathrm{plant}$ ). Gardener and Horanic (1961) reported higher yield production of sweet orange on rough lemon than sour orange rootstock. Bajwa et al., (1972) also reported similar findings highest mean fruit yield per tree of 249.9 fruits per tree and 201.3 per tree was recorded in Nucellar and Sathgudi, respectively. The probable reason for obtaining higher yield in Valencia late variety is that due to more fruit set percentage and by adapting good cultural and management practices along with highest photosynthesis assimilates and storage food material leads to maximum fruit yield per plant. Similar result were also recorded by Sharma et al., (1986) in Mango and Niskhare (2002) in Acid lime

Valencia Late showed maximum juice percentage (53.13) followed by Hamlin (42.58), Sathgudi (38.67) and jaffa (37.00). Similar finding observed by Khalil et al., (1978) reported that Valencia late, Blood red and Mosambi produce more juice content. The results further showed (Table 2) that maximum TSS $\left(12.1^{\circ}\right.$ Brix) was also recorded in Valencia Late while Sathgudi, Hamlin and Blood Red malta showed the average TSS of 11.10, 10.26 and 9.66, respectively. Minimum TSS (8.2 ${ }^{\circ}$ Brix) was recorded in Pera. Maximum acidity $(1.07 \%)$ was recorded in Pera against minimum in Sathgudi (0.51\%). 
Table.1 Growth characteristics and yield of different sweet orange varieties

\begin{tabular}{|c|c|c|c|c|c|}
\hline Variety & $\begin{array}{c}\text { Plant } \\
\text { height }(\mathrm{m})\end{array}$ & $\begin{array}{c}\text { Plant } \\
\text { spread }(\mathrm{m})\end{array}$ & $\begin{array}{c}\text { Plant } \\
\text { volume }\left(\mathrm{m}^{3}\right)\end{array}$ & $\begin{array}{c}\text { No. of } \\
\text { fruit/plant }\end{array}$ & $\begin{array}{c}\text { fruit yield } \\
(\mathrm{Kg} / \text { plant })\end{array}$ \\
\hline Pear & 2.81 & 3.06 & 13.81 & 62.83 & 10.09 \\
\hline Pineapple & 3.37 & 3.68 & 23.95 & 76.40 & 12.73 \\
\hline Jaffa & 4.07 & 3.65 & 28.47 & 131.72 & 16.47 \\
\hline W. Navel & 3.94 & 3.05 & 25.32 & 163.61 & 20.19 \\
\hline Hamlin & 3.74 & 3.80 & 28.25 & 145.15 & 20.98 \\
\hline Valencia late & 4.42 & 4.17 & 40.31 & 232.76 & 32.75 \\
\hline Sathgudi & 3.23 & 3.76 & 23.88 & 220.00 & 29.32 \\
\hline Blood redmalta & 4.15 & 3.90 & 33.07 & 186.85 & 23.35 \\
\hline SEm $( \pm)$ & 0.17 & 0.08 & 0.77 & 4.38 & 0.93 \\
\hline CD at 5\% & 0.54 & 0.24 & 2.32 & 13.24 & 2.83 \\
\hline
\end{tabular}

Table.2 Chemical composition of different varieties of sweet orange

\begin{tabular}{|c|c|c|c|c|}
\hline Variety & $\begin{array}{c}\text { Juice } \\
\text { percentage }(\%)\end{array}$ & $\begin{array}{c}\text { TSS } \\
\left({ }^{0} \text { Brix }\right)\end{array}$ & Acidity (\%) & $\begin{array}{c}\text { Ascorbic acid } \\
\text { (mg/100ml juice) }\end{array}$ \\
\hline Pera & 25.34 & 8.20 & 1.07 & 51.81 \\
\hline Pineapple & 21.42 & 9.00 & 0.96 & 46.61 \\
\hline Jaffa & 37.00 & 9.37 & 0.72 & 51.10 \\
\hline W. Navel & 36.48 & 9.65 & 0.62 & 51.36 \\
\hline Hamlin & 42.58 & 10.26 & 0.61 & 53.02 \\
\hline Valencia late & 53.13 & 12.10 & 1.01 & 57.86 \\
\hline Sathgudi & 38.67 & 11.10 & 0.51 & 51.50 \\
\hline Blood red malta & 35.23 & 9.66 & 0.84 & 54.04 \\
\hline SE(m) & 0.60 & 0.29 & 0.06 & 1.48 \\
\hline CD at 5\% & 1.83 & 0.88 & 0.20 & 4.46 \\
\hline
\end{tabular}

In citrus fruits, the acidity increases during development reaching levels below optimal for enzymatic activity Significant variation was observed in ascorbic acid content of sweet orange fruit of different varieties. Significantly maximum ascorbic acid (57.86 $\mathrm{mg} / 100 \mathrm{ml}$ ) was found in variety Valencia late which at par with variety Blood red malta $(54.04 \mathrm{mg} / 100 \mathrm{ml})$. The minimum ascorbic acid content was recorded in variety Pineapple $(46.61 \mathrm{mg} / 100 \mathrm{ml})$. The increase in ascorbic acid was associated with rapid increase in total sugar as the fruit synthesizes ascorbic acid from hexose sugar precursors
(Mapson, 1970). The respiration rate decreased with increasing maturity of fruit.

\section{References}

A.O.A.C., 1985. Official methods of analysis. Association of official analytical chemists. Washington, D.C. (USA).

Ahmad, W., M.A. Prevez, M. Amjad, M. Khalid, C.M. Ayyub and M.A. Nawaz, 2006. Effect of stionic combination on the growth and yield of Kinnow mandarin (Citrus reticulate Blanco). Pakistan J. Bot., 38: 603-612 
Aziz, A.B.Z.A., 1963. Descriptive studies of various varieties of sweet orange (Citrus sinensis Linn.) from their distinguishing tree, foliage, fruit and growth characters. M.Sc. Thesis, WPAU, Lyallpur

Bajwa, M.S., M.R. Gupta and J.R. Sharma, 1972. A varietal trial on sweet orange (Citrus sinensis (L) Osbeck). Punjab Hort. J., 22 (1-2): 45-47.

Gardner, F. E. and G.E. Hornic, 1961. A comparative evaluation of rootstocks for Valencia and Person Brown oranges on Lake land and fines and. Proc. Fla. sta. Hort. Soc., 74:123-7

Ingle, H. V, P. B. Gode, B. G. Banbote and G. K. Giri, 2004. Release proposal of PDKV, lime submitted to state varietal realease committee

Khalil, J.K., I. Ahmad, M. Saeed and N. Habib, 1978.Variation in the chemical composition of citrus fruits at different stages of maturity. J. Sci. and Tech. 2(12): $1-6$

Madhavi, M. and K.H. Babu, 2003.Performance of certain sweet orange varieties in Andhra Pradesh. Madras Agric J., 90 (7-9): 560-562.

Mapson, L. W., 1970. Vitamin in fruits. In: The Biochemistry of fruits and their products. (ed. Hulme, A. C.) Academic press, New York. Vol. 1: 369-386

Mehrotra, N. K., J. S. Jawanda and V. K. Vij, 1977. A Comporative evaluation of rootstocks for Blood red orange $[C$.
Sinensis (L) under arid-irrigated conditions of Punjab. Paper presented in the International Symposium on Citriculture, Bangalore

Nikhare, A.K., 2002. Effect of plant growth regulators on flowering, yield and quality of Hasta bahar acid lime. M.sc. (Agri.) Thesis (unpub), Dr. PDKV., Akola.

Patil, F., S.S. Digrase, S.D. Vasmate, S.S. Pawar and S.S. Sarsamkar, 2007.Comparative study of Nucellar and Sathgudi mosambi (Citrus sinensis Osbeck). under. Parbhani condition. AsianJ.Horti.Vol.2(1):111-113.

Richardson, A., P. Andersen, A. Hartey and P. Sutton, 1991. Satsuma ten cultivar compared. Orchardist of New Zealand, 64(2): 22-25.

Roose, M.L., D.A. Cole, D. Atkin and R.S. Kuper, 1986. Yield and tree size of four citrus cultivars on 21 root stocks in California. J. Amer. Soc. Hort. Sci. 114: 135-140.

Sharma, T.R., P.K.R. Nair and M.K. Nema, 1986. Influence of foliar spray of Urea, $\mathrm{KNO}_{3}$ and NAA on chemical composition of Mango cv. Langra. Punjab Hort.J.18(1/2):53-56.

Shinde, N. N., S. D. Jature, M. B. Patil and V. N. Shinde, 2004. Seedless lime a promising mutant of acid lime. J. Maharashtra agric. Univ., 29 (2): $227-$ 22.

\section{How to cite this article:}

Polu Parameshwar, P.S. Joshi and Nagre, P.K. 2018. Effect of Rootstock on Plant Growth and Fruit Quality of Sweet Orange (Citrus sinensis var. Valencia late). Int.J.Curr.Microbiol.App.Sci. 7(04): 1685-1689. doi: https://doi.org/10.20546/ijcmas.2018.704.190 